\title{
Effect of Cadmium on DNA Changes in Ipomoea aquatica Forssk.
}

\author{
Tawatchai Tanee ${ }^{1,2}$, Runglawan Sudmoon ${ }^{2,3}$, \\ Penkhae Thamsenanupap ${ }^{1}$, Arunrat Chaveerach ${ }^{2,3 *}$ \\ ${ }^{1}$ Faculty of Environment and Resource Studies, Mahasarakham University, \\ Maha Sarakham 44150, Thailand \\ ${ }^{2}$ Genetics and Environmental Toxicology (GET) Research Group, Khon Kaen University, \\ Khon Kaen 40002, Thailand \\ ${ }^{3}$ Department of Biology, Faculty of Science, Khon Kaen University, \\ Khon Kaen 40002, Thailand
}

Received: 13 September 2015

Accepted: 10 November 2015

\begin{abstract}
Cadmium $(\mathrm{Cd})$ contamination in plants fertilized with inorganic fertilizers is a major risk to human health. Ipomoea aquatica Forssk., which is one of the most popular vegetables used in Thai cuisine, is also vulnerable to Cd contamination. This study aimed to investigate $\mathrm{Cd}$ accumulation in Ipomoea aquatica Forssk. and the associated changes in its DNA. The plant was grown in soil supplemented with $\mathrm{Cd}$ at $0,15,30$, 60 , and $120 \mathrm{mg} / \mathrm{kg}$. After 21 days, accumulation in the roots, stems, and leaves was analyzed using atomic absorption spectrophotometry (AAS), and the bioconcentration (BCF) and translocation factors (TF) were analyzed. DNA changes were assessed by a combination of random amplified polymorphic DNA (RAPD) and genomic template stability (GTS) tests. Cd concentrations in the roots, stems, and leaves ranged from 0 to $12,333 \mathrm{mg} / \mathrm{kg}, 0$ to $5,909.27 \mathrm{mg} / \mathrm{kg}$, and 0 to $1,653.26 \mathrm{mg} / \mathrm{kg}$, respectively. The BCF and TF values ranged from 0 to 21.15 and 0 to 1.21 , respectively. From the RAPD profiles, the GTS values ranged from 52.3 to $91.1 \%$. Taken together, these results indicate that I. aquatica is a Cd-hyperaccumulator; therefore, consuming I. aquatica plants grown in Cd-polluted areas is a health risk.
\end{abstract}

Keywords: cadmium, Ipomoea aquatica Forssk., bioconcentration factor, translocation factor, genotoxicity

\section{Introduction}

Cadmium $(\mathrm{Cd})$ is a heavy metal that has been used extensively in the agricultural and chemical industries as a component of inorganic fertilizers, pesticides, and

*e-mail: raccha@kku.ac.th paints, and it can be released into the soil and water. Humans are mainly exposed to $\mathrm{Cd}$ via the food supply. $\mathrm{Cd}$ accumulation in the food chain could pose a direct threat to human health and can cause disease (e.g., itaiitai disease, cancer), damage to the skeletal system, high blood pressure, adverse cardiovascular events, enzyme inhibition, and DNA damage [1]. Cd also causes chronic toxicity in animals [2]. The World Health Organization 
[3] has established a provisional tolerable weekly intake of $7 \mu \mathrm{g}$ of $\mathrm{Cd}$ per $\mathrm{kg}$ of body weight, whereas the $\mathrm{Cd}$ concentration in the soil should be less than $37 \mathrm{mg} / \mathrm{kg}$ [4], and the concentration in the leaves of edible plants should be $<0.2 \mathrm{mg} / \mathrm{kg}[5]$.

In Cd-contaminated soil, plants can take up the metal through the roots and then translocate it to the stems and leaves via physio-biochemical mechanisms. Cd contamination in agricultural soils is unlikely to affect plant growth, but $\mathrm{Cd}$ is easily transferred from soil to the human food chain. Moreover, an excess of toxic heavy metal ions induces several cellular stress responses and damages different cellular components of the plant, such as membranes, proteins, and DNA $[1,6]$. Ipomoea aquatica is a popular vegetable in northeastern Thailand and other Asian countries. Knowledge regarding $\mathrm{Cd}$ accumulation and DNA damage in edible plant species should be expanded.

Recently, the development of molecular technology has provided suitable tools for DNA analysis in the field of genotoxicology. In many studies, random amplified polymorphic DNA(RAPD) has been used to detect various types of DNA damage and mutations (point mutations, rearrangements, and small deletions or insertions). Furthermore, RAPD banding profiles can be scored for genomic template stability (GTS) analysis to detect changes in DNA. This technique has been successfully applied to the study of DNA damage and mutation caused by heavy metals in plants and animals [6-11].

The aims of this study were to determine the $\mathrm{Cd}$ content in different plant parts, including the roots, stems, and leaves, and to detect Cd-induced changes in Ipomoea aquatica DNA using RAPD markers.

\section{Materials and Methods}

\section{Soil Collection and Experimental Design}

The tested soil was collected from an agricultural field in Maha Sarakham Province, Thailand, and analyzed to determine the $\mathrm{Cd}$ concentration before initiating the experiments. The collected surface soil samples (depth of 0-30 cm) were supplemented with $\mathrm{Cd}\left(\mathrm{CdCl}_{2} \cdot 2.5 \mathrm{H}_{2} \mathrm{O}\right.$; Univar, Australia) at five concentrations: 0 (no supplementation), 15, 30, 60, and $120 \mathrm{mg} / \mathrm{kg}$. Samples (1 $\mathrm{kg})$ of the supplemented soils were placed into individual plastic pots. Seeds of I. aquatica (Chia Tai Seed Co. Ltd., Thailand) were sown to obtain five seedlings in each pot. Each treatment was replicated three times and arranged in a completely randomized design. To simulate field conditions, the plants were grown under open field conditions with added organic fertilizers. After 21 days of experimentation, the leaves were collected for DNA analysis. All of the plants and soil samples were used to determine $\mathrm{Cd}$ accumulation.

The field-collected soil samples (collected before the experiments) and the soil samples collected from each pot (collected after the experiments) were dried in an oven (Binder, USA) at $105^{\circ} \mathrm{C}$ for $24 \mathrm{~h}$. The plants were dissected into roots, stems, and leaves and then rinsed thoroughly with distilled water to remove any surface materials. After complete drying, the dried samples were ground with a mortar and pestle. One gram of each dried sample (soils and plant parts) was added to $12 \mathrm{ml}$ of an $\mathrm{HClO}_{4}: \mathrm{HNO}_{3}$ mixture $(1: 3)$ and boiled at $100^{\circ} \mathrm{C}$ [12]. The solutions were filtered to obtain clear liquids, which were brought up to a volume of $50 \mathrm{ml}$ in a volumetric flask with deionized-distilled water. The digested samples were analyzed for Cd using an AA 6200 atomic absorption spectrophotometer (Shimadzu, Japan). All analyses were performed in triplicate.

\section{DNA Extraction}

Total genomic DNA was extracted using the cetyltrimethylammonium bromide (CTAB) method according to Porebski et al. [13]. Briefly, $50 \mathrm{mg}$ of each leaf sample was finely ground in $600 \mu 1$ of warm $\left(65^{\circ} \mathrm{C}\right)$ extraction buffer (100 mM Tris- $\mathrm{HCl}, \mathrm{pH} 8.0,1.4 \mathrm{M} \mathrm{NaCl}$, $20 \mathrm{mM}$ EDTA, 2\% CTAB) with a mortar and pestle. The homogenate was transferred to a $1.5-\mathrm{ml}$ microcentrifuge tube; subsequently, $5 \mu 1$ of $10 \mathrm{mg} / \mathrm{ml}$ RNase A was added, and the samples were incubated at $65^{\circ} \mathrm{C}$ for $30 \mathrm{~min}$. An equal volume of chloroform-isoamyl alcohol (24:1 v/v) was then added. The tube was centrifuged at $8,000 \times \mathrm{g}$ for $10 \mathrm{~min}$, and the aqueous phase was transferred to a new tube. Finally, genomic DNA was precipitated with an equal volume of cold $\left(-20^{\circ} \mathrm{C}\right)$ 2-propanol for $30 \mathrm{~min}$ and then centrifuged. The precipitate was washed with $70 \%$ ethanol and resuspended in TE buffer $(10 \mathrm{mM}$ Tris- $\mathrm{HCl}$, $1 \mathrm{mM}$ EDTA, pH 8.0). Extracted DNA was examined by $0.8 \%$ agarose gel electrophoresis and ethidium bromide staining.

\section{RAPD Procedures}

RAPD amplifications were carried out in $25-\mu$ l reactions consisting of GoTaq Green Master Mix (Promega, USA), $0.5 \mu \mathrm{M}$ primers (Invitrogen, USA), and $20 \mathrm{ng}$ of DNA template. Eighteen RAPD primers were screened, and the 10 primers that successfully amplified clear bands were as follows (5'-3'): GCGGCTGGAG, GTGACGCCGC, CTCGGGTGGG, TTCCGCGGGC, GTAGACGAGC, GTGCGTCCTC, CTGGCGGCTG, CGTGGGCAGG, AGCAGCGTGG, and GCCTGGTTGC. In a Swift Maxi Thermal Cycler (Esco Micro Pte. Ltd., Singapore), the reaction mixture was denatured at $94^{\circ} \mathrm{C}$ for $3 \mathrm{~min}$, and amplification was performed by 35 cycles of the following: denaturation for $30 \mathrm{~s}$ at $94^{\circ} \mathrm{C}$, annealing for $30 \mathrm{~s}$ at $40^{\circ} \mathrm{C}$, and extension for $2 \mathrm{~min}$ at $72^{\circ} \mathrm{C}$ followed by a 7-min final extension at $72^{\circ} \mathrm{C}$. The amplified products were separated by $1.2 \%$ agarose gel electrophoresis in TAE buffer and visualized using ethidium bromide staining. The resulting RAPD bands were used to analyze the percentage of GTS 


\section{Data Analysis}

All experiments were replicated three times. The means and standard deviations (SD) of $\mathrm{Cd}$ in the soil and plant parts were calculated using Microsoft Office Excel 2010. The bioconcentration factor (BCF) was calculated as the ratio of the $\mathrm{Cd}$ concentration in the plant root to that in the soil, whereas the translocation factor (TF) was calculated as the ratio of the $\mathrm{Cd}$ concentration in the plant shoot to that in the root [14]. Cd-hyperaccumulating plants were defined based on the following standards:

1) accumulation capability corresponding to a threshold shoot metal concentration greater than $100 \mathrm{mg} / \mathrm{kg}$ shoot dry weight,

2) a $\mathrm{BCF}$ index greater than 1.0 , sometimes reaching 50-100,

3) a TF index used to measure a plant's ability to translocate metal from the roots to the shoots [15-17], greater than 1.0.

A GTS test was performed using the following equation: $\operatorname{GTS}(\%)=(1-\mathrm{a} / \mathrm{n}) \times 100$, where ' $\mathrm{a}$ ' is the number of polymorphic bands detected in each treated sample and ' $n$ ' is the number of total bands in the control [9]. The polymorphisms observed in the RAPD profiles included the disappearance of a normal band and the appearance of a new band when compared with the control RAPD profiles.

\section{Results and Discussion}

In the present investigation, plant heights ranged from 1.6 to $9.7 \mathrm{~cm}$. Before the experiments, the field soils contained $14.92 \pm 1.18 \mathrm{mg} \mathrm{Cd} / \mathrm{kg}$ soil. The amount and distribution of $\mathrm{Cd}$ in the I. aquatica parts treated with different concentrations $(0,15,30,60,120 \mathrm{mg} \mathrm{Cd} / \mathrm{kg})$ are shown in Table 1. Cd concentrations in the roots, stems, and leaves ranged from 0 to $12,333 \mathrm{mg} / \mathrm{kg}$, 0 to $5,909.27$ $\mathrm{mg} / \mathrm{kg}$, and 0 to $1,653.26 \mathrm{mg} / \mathrm{kg}$, respectively. The mean $\mathrm{Cd}$ concentration in different parts of the plant increased in the following sequence: leaves $<$ stems $<$ roots. This result is concordant with previous research showing that roots can accumulate $\mathrm{Cd}$ from the soil more robustly than stems and leaves [18]. The concentration of $\mathrm{Cd}$ in all parts of the plant increased with increasing concentrations of $\mathrm{Cd}$ supplemented in the soils, and there was a positive linear correlation between the root, stem, and leaf Cd uptake and $\mathrm{Cd}$ concentrations in the soils. The corresponding regression equations can be expressed as follows:

$$
\begin{array}{ll}
Y_{R}=101.64 X+306.31 & \left(R^{2}=0.99\right) \\
Y_{S}=38.539 X+946.76 & \left(R^{2}=0.87\right) \\
Y_{L}=10.183 X+505.63 & \left(R^{2}=0.91\right)
\end{array}
$$

...where $Y_{R}, Y_{S}$, and $Y_{L}$ are the $C d$ concentrations in the roots, stems, and leaves, respectively, and $\mathrm{X}$ is the concentration of $\mathrm{Cd}$ in the soil.

The BCF value represents a plant's ability to accumulate $\mathrm{Cd}$ from the soil, and the TF value represents a plant's ability to translocate $\mathrm{Cd}$ from the roots to the shoots. In the present investigation, $\mathrm{BCF}$ and $\mathrm{TF}$ ranged from 0 to 21.15 and from 0 to 1.21 , respectively (Table 1 ). Thus, the concentration in the shoots increased with an increasing $\mathrm{Cd}$ concentration in the soil. These results are concordant with previous research showing that plants can accumulate $\mathrm{Cd}$ from the soil [18-20]. Cd-hyperaccumulator plants can contain $>100 \mathrm{mg} \mathrm{Cd} / \mathrm{kg}$ tissue, whereas the normal level of Cd in most plants is only $0.1 \mathrm{mg} / \mathrm{kg}$. In addition to the total $\mathrm{Cd}$ content, the $\mathrm{BCF}$ and $\mathrm{TF}$ indices must also be considered when evaluating hyperaccumulators, and hyperaccumulating plants should have a BCF and $\mathrm{TF}>1$ [15-17]. In this study, the concentration of $\mathrm{Cd}$ in both stems and leaves ranged from 491 to $5,909 \mathrm{mg} / \mathrm{kg}$, and the BCF and TF indices were higher than 1 (Table 1). All of the values exceeded critical levels; therefore, $I$. aquatica can be defined as a Cd-hyperaccumulator.

$\mathrm{Cd}$ accumulation in edible plants is a serious problem not only because it could reduce crop yield but also because it is a hazard to human health through the food chain. Ipomoea aquatica is one of the most popular vegetables used in Thai cuisine. Based on the high level of $\mathrm{Cd}$ accumulation in I. aquatica, plants that grow in contaminated soils are not recommended for human consumption. Cd toxicity can pose direct threats to human health via the food chain, and it can cause disease (e.g., itai-itai disease, cancer), damage to the skeletal system,

Table 1. Cadmium accumulation, bioconcentration factor (BCF), translocation factor (TF), and genomic template stability (GTS) of Ipomoea aquatica under various Cd treatments.

\begin{tabular}{|c|c|c|c|c|c|c|}
\hline \multirow{2}{*}{ Cd conc. (mg/kg) } & \multicolumn{3}{|c|}{$\begin{array}{c}\text { Accumulated Cd (mg/kg) in plant parts } \\
\text { (mean } \pm \text { SD) }\end{array}$} & \multirow{2}{*}{ BCF } & TF & \multirow{2}{*}{ GTS (\%) } \\
\cline { 2 - 6 } & Root & Stem & Leaf & & & \\
\hline 0 (control) & 0 & 0 & 0 & 0 & 0 & - \\
\hline 15 & $1,873.55 \pm 918.20$ & $1,612.50 \pm 825.62$ & $491.16 \pm 266.53$ & 12.58 & 1.12 & 91.1 \\
\hline 30 & $2,950.83 \pm 1,817.87$ & $2,647.13 \pm 1,573.62$ & $913.23 \pm 448.51$ & 15.85 & 1.21 & 76.6 \\
\hline 60 & $6,937.45 \pm 3,003.51$ & $2,289.40 \pm 1,235.15$ & $1,256.13 \pm 643.78$ & 21.15 & 0.51 & 55.5 \\
\hline 120 & $12,333.00 \pm 6,413.73$ & $5,909.27 \pm 2,854.82$ & $1,653.26 \pm 748.66$ & 16.84 & 0.61 & 52.3 \\
\hline
\end{tabular}




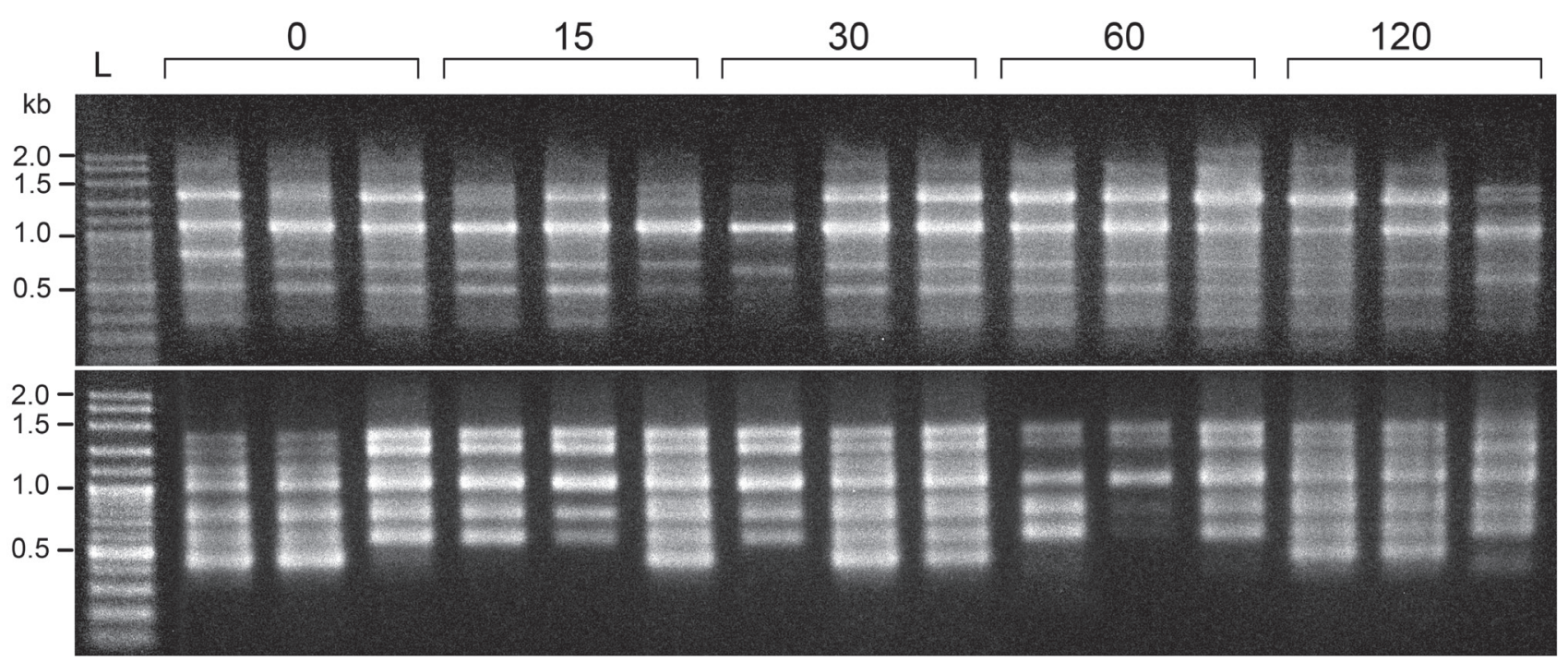

Fig. 1. RAPD profiles using primers CGTGGGCAGG (top) and CTGGCGGCTG (bottom) of Ipomoea aquatica exposed to different concentrations of Cd: 0 (control), 15, 30, 60, and $120 \mathrm{mg} / \mathrm{kg}$.

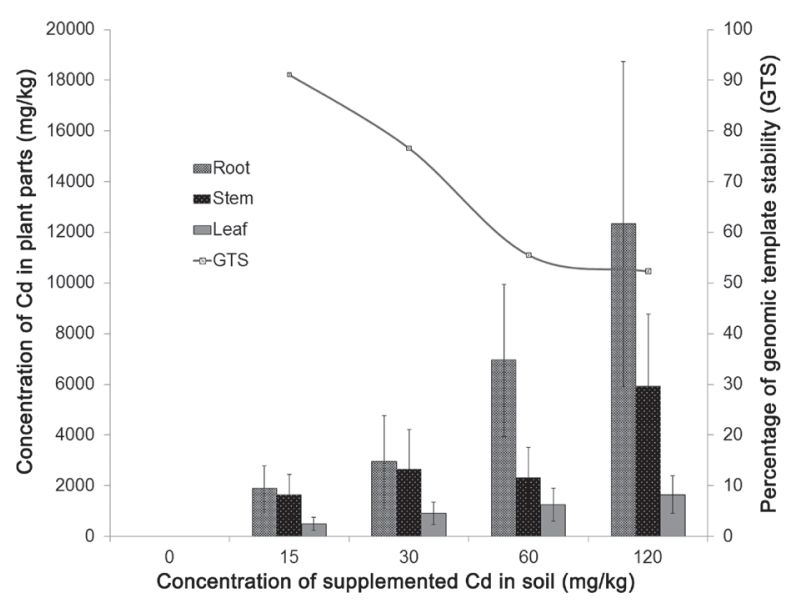

Fig. 2. Comparison of $\mathrm{Cd}$ accumulation and GTS values in Ipomoea aquatica.

adverse cardiovascular events, enzyme inhibition, DNA damage in humans [1], and chronic toxicity in animals [2].

An example of the RAPD banding patterns observed in RAPD fingerprinting experiments is shown in Fig. 1. There were substantial differences in the RAPD profiles between the control and treated plants, with apparent changes (disappearance and/or appearance) in the number of DNA bands produced by each primer. The GTS values ranged from 52.3 to $91.1 \%$ (Table 1). The highest concentration of $\mathrm{Cd}$ supplementation $(120 \mathrm{mg} / \mathrm{kg})$ caused the most extensive changes in the plant DNA $(\mathrm{GTS}=52.3 \%)$. These results indicate that the GTS value in I. aquatica was affected by $\mathrm{Cd}$ exposure. A decrease in GTS values was observed with an increase in the Cd concentration (Fig. 2 and Table 1). These results correlated with previous data suggesting that $\mathrm{Cd}$ could induce changes in plant DNA [6, $8,10,18]$.

\section{Conclusion}

$\mathrm{Cd}$ accumulation in plant species can affect growth. In the current study, Cd-induced DNA damage in I. aquatica was evidenced by the results of the RAPD assay. Ipomoea aquatica can accumulate $\mathrm{Cd}$ at concentrations greater than $100 \mathrm{mg} / \mathrm{kg}$, whereas the normal level of $\mathrm{Cd}$ in most plants is only $0.1 \mathrm{mg} / \mathrm{kg}$. This high level of accumulation, in addition to the high values of BCF and TF, suggests that I. aquatica is a Cd-hyperaccumulator. Therefore, consumers should be concerned that consumption of plants grown in Cd-polluted areas poses a health risk. The results of this study can be used as a basis for the development of food safety guidelines for farmers and others, especially guidelines pertaining to the use of pesticides, herbicides, or fertilizers.

\section{Acknowledgements}

The authors are thankful for the financial support provided by the Mahasarakham University Development Fund and by the Genetics and Environmental Toxicology (GET) Research Group at Khon Kaen University.

\section{References}

1. MANAHAN S.E. Toxicological Chemistry and Biochemistry. CRC Press; 449, USA, 2003.

2. MIURA N., ASHIMORI A., TAKEUCHI A., OHTANI K., TAKADA N., YANAGIBA Y., MITA M., TOGAWA M., HASEGAWA T. Mechanisms of cadmium-induced chronotoxicity in mice. J. Toxicol. Sci., 38 (6), 947, 2013.

3. WHO. Evaluation of certain food additives and contaminants: forty-first report of the Joint FAO/WHO Expert Committee on Food Additives. WHO Technical Report Series; 837, 1993. 
4. MINISTRY OF PUBLIC HEALTH, THAILAND. Announcement of Ministry of Public Health No. 98 (1986), Standard Level on Contaminants in Foods, 1986.

5. THE COMMISSION OF THE EUROPEAN COMMUNITIES. Commission Regulation (EC) No 1881/2006 of 19 December 2006 setting maximum levels for certain contaminants in foodstuffs. Official Journal of the European Union, 364, 24, 2006.

6. LIU W., LI P.J., QI X.M., ZHOU Q.X., ZHENG L., SUN T.H., YANG Y.S. DNA changes in barley (Hordeum vulgare) seedlings induced by cadmium pollution using RAPD analysis. Chemosphere, 61, 158, 2005.

7. ATIENZAR F.A., CONRADI M., EVENDEN A.J., JHA A.N., DEPLEDGE M.H. Qualitative assessment of genotoxicity using random amplified polymorphic DNA: comparison of genomic template stability with key fitness parameters in Daphnia magna exposed to benzo[a]pyrene. Environ. Toxicol. Chem., 18 (10), 2275, 1999.

8. LIU W., YANG Y.S., LI P.J., ZHOU Q.X., XIE L.J., HAN Y.P. Risk assessment of cadmium-contaminated soil on plant DNA damage using RAPD and physiological indices. J. Hazard. Mater., 161, 878, 2009.

9. LIU W., YANG Y.S., ZHOU Q., XIE L., LI P., SUN T. Impact assessment of cadmium contamination on rice (Oryza sativa $\mathrm{L}$.) seedlings at molecular and population levels using multiple biomarkers. Chemosphere, 67, 1155, 2007.

10. DUMAN D.C., ALTUNKAYNAK E., ARAS, E.S. Heavy metal accumulation and genotoxicity indicator capacity of the lichen species Ramalina pollinaria collected from around an iron steel factory in Karabük, Turkey. Turk. J. Bot., 38, 14, 2014.

11. BOONMEE S., NEERATANAPHAN L., TANEE T., KHAMON P. The genetic differentiation of Colocasia esculenta growing in gold mining areas with arsenic contamination. Environ. Monit. Assess., 187, 227, 2015.

12. TANEE T., CHAVEERACH A., NARONG C., PIMJAI
M., PUNSOMBUT P., SUDMOON R. Bioaccumulation of heavy metals in fish from the Chi River, Maha Sarakham province, Thailand. Int. J. Biosci., 3, 159, 2013.

13. POREBSKI S., BAILEY L.G., BAUM B.R. Modification of a CTAB extraction protocol for plants containing high polysaccharides and polyphenol component. Plant Mol. Biol. Report., 15, 8, 1997.

14. MALIK R.N., HUSAIN S.Z., NAZIR I. Heavy metal contamination and accumulation in soil and wild plant species from industrial area of Islamabad, Pakistan. Pakistan J. Bot., 42, (1), 291, 2010.

15. SUN Y., ZHOU Q., DIAO C. Effects of cadmium and arsenic on growth and metal accumulation of Cd-hyperaccumulator Solanum nigrum L. Bioresour. Technol., 99, 1103, 2008.

16. SUN Y., ZHOU Q., WANG L., LIU W. Cadmium tolerance and accumulation characteristics of Biden spilosa L. as a potential Cd-hyperaccumulator. J. Hazard. Mater., 161, 808, 2009.

17. LORESTANI B., CHERAGHI M., YOUSEFI N. Phytoremediation potential of native plants growing on a heavy metals contaminated soil of copper mine in Iran. World Acad. Sci. Eng. Technol. 5, 365, 2011.

18. SUDMOON R., NEERATANAPHAN L., THAMSENANUPAP P., TANEE T. Hyperaccumulation of cadmiumand DNA changes in popular vegetable, Brassica chinensis L. Int. J. Environ. Res., 9 (2), 433, 2015.

19. QIN T., WU Y., WANG H. Effect of cadmium, lead and their interactions on the physiological and biochemical characteristics of Brassica chinensis. Acta Ecol. Sin., 14, 46, 1994.

20. YAN S., LING Q., BAO Z., CHEN Z., YAN S., DONG Z., ZHANG B., DENG B. Cadmium accumulation in pakchoi (Brassica chinensis L.) and estimated dietary intake in the suburb of Hangzhou city, China. Food Addit. Contam. Part B Surveill., 2, 74, 2009. 
